\title{
Labour consumption in blackcurrant production
}

\author{
MARITTA YLÄRANTA and VILJO RYYNÄNEN
}

Department of Agricultural Economics, University of Helsinki, SF-00710 Helsinki 71

Abstract. Twenty-nine blackcurrant growers participated in the study, which took place between 19771980. The purpose of the study was to establish how much time was spent in preparing the fallow ground, planting, cultivating and harvesting blackcurrants. The total area of blackcurrant cultivation included in the study was 136,7 ha.

The work involved in establishing an area of one hectare for blackcurrant cultivation took 147,0 man hours using methods which were only slightly mechanized and 98,5 man hours using more mechanized methods. The corresponding tractor hours were 37,0 and 38,0 . In the normal fruit-bearing years (following the third growth period) cultivating tasks took 158,5 man hours and 9,5 tractor hours using slightly mechanized methods. With more mechanized methods, the labour consumption was 95,0 man hours and 24,0 tractor hours per hectare. Harvesting with a mechanical harvester took 37,5 man hours, 6,0 harvester hours and 8,0 tractor hours per hectare. The corresponding average yield was $3300 \mathrm{~kg} / \mathrm{ha}$. An average of $4000 \mathrm{~kg} / \mathrm{ha}$ were harvested by baton, accounting for 400,0 man hours and 6,0 tractor hours per hectare. The bushes were handpicked after mechanical harvesting. $800 \mathrm{~kg} / \mathrm{ha}$ were picked in 210,5 hours.

\section{Introduction}

The purpose of the 1977-1980 study was to establish the amount of working time consumed in the various stages of blackcurrant production, viz. in the planting summer, the summer after planting, first fruiting year and fruiting years. The different cultivation and harvesting methods were treated separately.

\section{Material and methods}

Of the total of 29 growers participating in the study, the number taking part each year varied from 7 to 21 . Correspondingly the total area of blackcurrant cultivation was 136,7 ha, while the area studied in an indivudual year varied from 27,8 ha to 50,2 ha. The area per farm varied from 0,2 ha to 14,0 ha and the average area per farm was 3,0 ha. Besides growing blackcurrant, most of the farmers were engaged in traditional farming and forestry or they had other work outside the farm. The farms were situated in south-west, east and central Finland. The variety Öjebyn was the most commonly cultivated, but Roodknop and Brödtorp were also grown to a lesser extent. 
The study method was the same as that in the study on the consumption of working time in strawberry cultivation. This method was reviewed in the publication YLÄRANTA and RYYNÄNEN (1981).

\section{Total labour and its distribution}

1) The fallow period and the planting

Though it is recommended that the ground lie fallow for a period of two years before planting, in practice this period is often no more than one year. The bushes are planted in the autumn, at the end of September or the beginning of October. The labour consumption during this fallow period and the planting summer is broken down in Table 1 . The planting machine used was either a forest planter or a planting machine constructed specially for garden plants.

Table 1. Labour consumption $(\mathrm{h} / \mathrm{ha})$ in establishing a blackcurrant cultivation.

\begin{tabular}{lcc}
\hline Task & Man hours & Tractor hours \\
\hline Ground preparation & 31,0 & 22,5 \\
Fertilizing & 10,0 & 5,5 \\
Planting: & & \\
A. Tractor-drawn plough+shovel & 86,0 & 9,0 \\
B. Tractor-drawn planting machine & 37,5 & 10,0 \\
Diverse & 20,0 & - \\
\hline Total: & & \\
A. & 147,0 & 37,0 \\
B. & 98,5 & 38,0 \\
\hline
\end{tabular}

In method $\mathrm{A}$ the bushes were planted in furrows ploughed by a tractor drawn plough. They were planted in intervals of $0,5-0,9 \mathrm{~m}$ and the rows were $3,5-4,0 \mathrm{~m}$ apart. The average number of plants per hectare was 4000 . The average labour output using planting method $\mathrm{A}$ was 47 plant per hour and 107 plant per hour using method B.

2) The summer following planting

Seven farms had one-year old cultivations covering a total area of 15,3 ha. Table 2 presents the average amount of labour involved in the various tasks.

Most of the labour involved went to weed control ( $42 \%)$. As frost has raised the plants during the winter, they had to be banked up with top soil in the spring. This was done using a tractor-drawn board and a shovel. There was little need for pruning at this phase of grouth. Diverse work included frost protection. The average yield was only $200 \mathrm{~kg} / \mathrm{ha}$.

3) The first fruiting year

The two-year-old cultivations were classified in a group of their own, as the yield and the need for pruning differ greatly from those of later years. The labour 
Table 2. Labour consumption ( $\mathrm{h} / \mathrm{ha}$ ) in blackcurrant cultivation during the summer following planting.

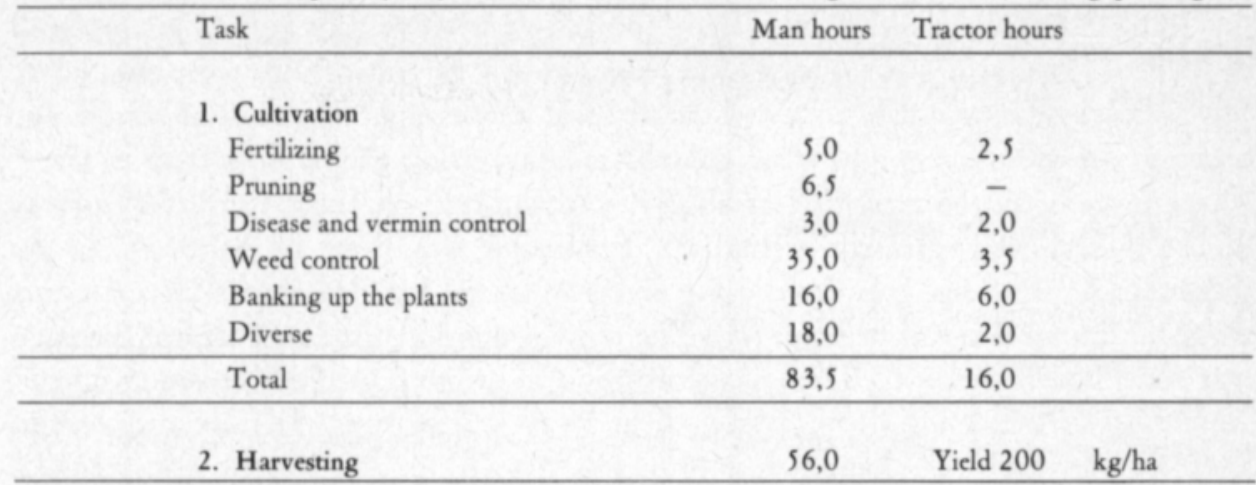

consumption in cultivation and harvesting tasks are presented in Table 3. Pruning, disease and vermin control and weed control each accounted for $21 \%$ of the total labour consumption. Two harvesting methods were used. The most common method with cultivations of this age ( 3 years) is the baton-picking. Batons consist of $40-50 \mathrm{~cm}$ long pieces of rubber or plastic tubing. The branches are struck with a baton and the berries drop off into a large fibre-glass vessel. Hand picking was applied only in those bushes in which the yield was very low.

Table 3. Labour consumption $(\mathrm{h} / \mathrm{ha})$ and yield in the first fruiting year of blackcurrant cultivation.

\begin{tabular}{|c|c|c|c|c|}
\hline Task & Man hours & & Tractor hours & \\
\hline \multicolumn{5}{|l|}{ 1. Cultivation } \\
\hline Fertilizing & 3,5 & & 0,5 & \\
\hline Irrigation & 6,5 & & 0,5 & \\
\hline Pruning & 18,0 & & 1,5 & \\
\hline Disease and vermin control & 7,5 & & 6,0 & \\
\hline Weed control & 18,0 & & 3,0 & \\
\hline Diverse & 18,0 & & 0,5 & \\
\hline Control & 16,0 & & - & \\
\hline Total & 87,5 & & 12,0 & \\
\hline \multirow[t]{2}{*}{ 2. Harvesting } & \multicolumn{2}{|c|}{ Man } & Tractor & \\
\hline & h/ha & $\mathrm{h} / 1000 \mathrm{~kg}$ & $\mathrm{~h} / \mathrm{ha}$ & $\begin{array}{c}\text { harvested } \\
\mathrm{kg} / \mathrm{ha}\end{array}$ \\
\hline A. Hand picking & 218,0 & 242,2 & 1,0 & 900 \\
\hline B. Baton picking ${ }^{1}$ & 210,0 & 116,5 & 2,0 & 1800 \\
\hline Diverse & 11,5 & - & - & - \\
\hline \multicolumn{5}{|l|}{ Total harvesting $\mathrm{h} / \mathrm{ha}$} \\
\hline Method A. & 229,5 & & 1,0 & \\
\hline -"- B. & 221,5 & & 2,0 & \\
\hline
\end{tabular}

1 Including cleaning the berries. 
4) Fruiting years

Labour consumption in cultivating full-grown blackcurrant bushes is presented in Table 4. The bushes are at least four years old. All the cultivations were planted in rows sufficiently far apart to allow mechanical harvesting. Methods of fertilizing, pruning, disease, vermin and weed control and harvesting varied from farm to farm. These tasks could be classified as slightly mechanized, on small farms (A) and as highly mechanized on large farms (B). Fertilizing was done by hand (A) or by spreader (B). Pruning was done using short and long-handled shears (A) or using shears and a mechanical trimmer (B). The most commonly used mechanical trimmer was the Finnish 'Joonas'. Labour consumption in pruning includes breaking up the trimmings or collecting them, taking them away and burning. Disease and vermin control was done by knapsack motor sprayer (A) or by tractor sprayer (B). Knapsack sprayer (A) or tractor and knapsack sprayers (B) were used in weed control.

On farms cultivating small areas blackcurrants (less than a hectare) baton picking was applied in harvesting; on the large farms harvester and baton. The method used also depended on the amount of berries on the bushes. Two types of harvesters - English Pattenden Straddle Harvester or Finnish Joonas Harvester were used. Picking by baton required 4-6 pickers per hectare. The pickers worked in pairs. The labour output $(\mathrm{kg} / \mathrm{man} / \mathrm{hour})$ was $88 \mathrm{~kg} / \mathrm{h}$ with a harvester, $10 \mathrm{~kg} / \mathrm{h}$ with batons and $4 \mathrm{~kg} / \mathrm{h}$ by hand.

Table 4. Labour consumption $(\mathrm{h} / \mathrm{ha})$ and yield $(\mathrm{kg} / \mathrm{ha})$ in blackcurrant cultivation during fruiting years.

\begin{tabular}{|c|c|c|c|c|c|}
\hline \multirow[t]{2}{*}{ Task } & \multicolumn{2}{|c|}{ Method A } & \multicolumn{2}{|c|}{ Method B } & \\
\hline & $\begin{array}{l}\text { Man } \\
\text { hours }\end{array}$ & $\begin{array}{l}\text { Tractor } \\
\text { hours }\end{array}$ & $\begin{array}{l}\text { Man } \\
\text { hours }\end{array}$ & $\begin{array}{l}\text { Tractor } \\
\text { hours }\end{array}$ & \\
\hline \multicolumn{6}{|l|}{ 1. Cultivation } \\
\hline Fertilizing & 9.0 & - & 6.0 & 2.5 & \\
\hline Irrigation & 11.0 & 4.0 & 11.0 & 4.0 & \\
\hline Pruning & 65.0 & 4.0 & 30.0 & 6.5 & \\
\hline \multicolumn{6}{|l|}{ Disease and } \\
\hline vermin control & 31.0 & - & 8.5 & 6.0 & \\
\hline Weed control & 17.5 & - & 14.5 & 3.5 & \\
\hline Diverse & 13.0 & 1.5 & 13.0 & 1.5 & \\
\hline Control & 12.0 & - & 12.0 & - & \\
\hline Total & 158.5 & 9.5 & 95.0 & 24.0 & \\
\hline \multirow[t]{2}{*}{ 2. Harvesting } & & & Tractor & Harvester & Yield \\
\hline & $\mathrm{h} / \mathrm{ha}$ & $\mathrm{h} / 1000 \mathrm{~kg}$ & $\mathrm{~h} / \mathrm{ha}$ & $\mathrm{h} / \mathrm{ha}$ & $\mathrm{kg} / \mathrm{ha}$ \\
\hline A. Baton ${ }^{1}$ & 400.0 & 100.0 & 6.0 & - & 4000 \\
\hline B. Harvester & 37.5 & 11.5 & 8.0 & 6.0 & 3300 \\
\hline (Hand picking ${ }^{2}$ ) & $(210.5)$ & $(263.1)$ & & $(-)$ & $(800)$ \\
\hline Supervision & 16.5 & & & & \\
\hline Diverse & 8.0 & & & & \\
\hline
\end{tabular}

Total

\begin{tabular}{lrrr} 
A. & 424.5 & 6.0 & - \\
B. & 62.0 & 8.0 & 6.0 \\
\hline
\end{tabular}

1 Including cleaning the berries.

2 After mechanical harvesting. 

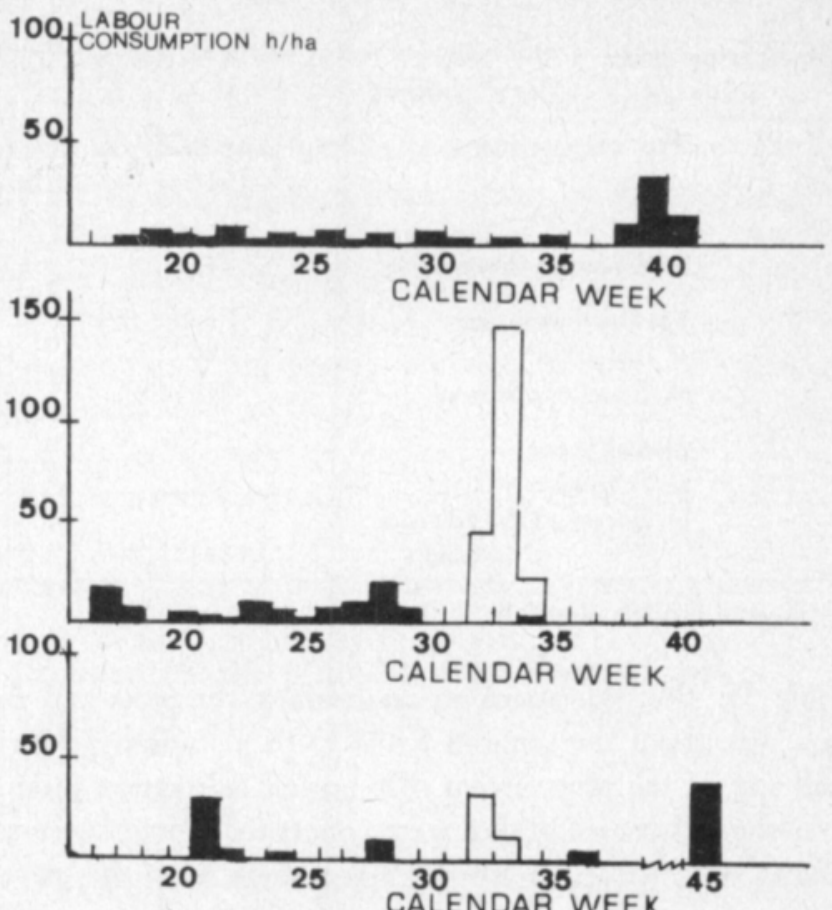

Fig. 1. The distribution of labour $(\mathrm{h} / \mathrm{ha})$ in blackcurrant production: planting (above), during the first fruiting year (second) and during normal fruiting years, by mechanical harvester (third) and by baton (below).

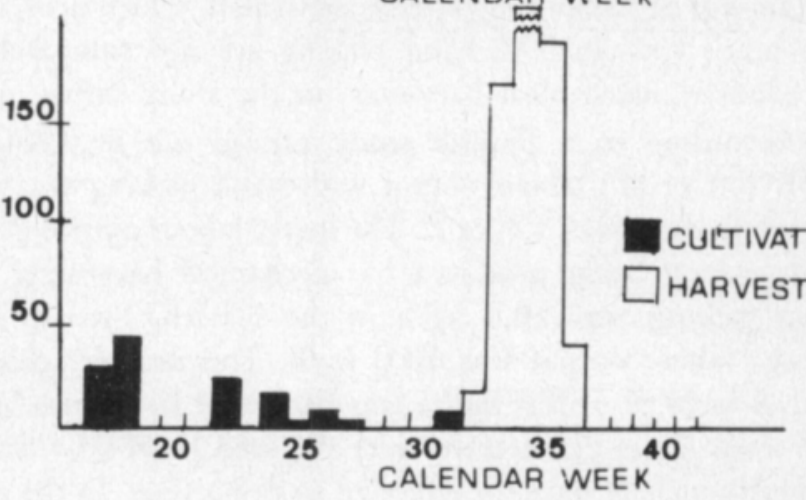

5) The distribution of working time per week

The distribution of working time per week is described in Figure 1. The diagram above illustrates the distribution of fallow tasks per week. The bushes had been planted mechanically in week 40 . The second diagram illustrates the first fruiting years. Baton and hand picking were the harvesting methods applied at this phase of cultivation. The two last diagrams show the normal fruiting years. In the first case the blackcurrants were harvested mechanically and in the second using batons and by hand.

\section{Discussion}

Not many studies have been made of the labour consumption in blackcurrant cultivation. KRẢKEVIK (1973) has reported on Norwegian studies. According to his study labour consumption was greater than that in the results presented here 
Table 5. Consumption of man hours per hectare and yield $(\mathrm{kg} / \mathrm{ha})$ in blackcurrant cultivation according to Norwegian and Finnish studies.

\begin{tabular}{|c|c|c|}
\hline Phase of cultivation & $\begin{array}{l}\text { KRÅKEVIK } \\
1973\end{array}$ & $\begin{array}{l}\text { Present } \\
\text { study }\end{array}$ \\
\hline Establishment of cultivation: & 243 & $123,0^{1}$ \\
\hline $\begin{array}{l}\text { The first fruiting year: } \\
\text { a) Cultivation } \\
\text { b) Harvesting by hand }\end{array}$ & $\begin{array}{l}99 \\
198(760)\end{array}$ & $\begin{array}{l}87,5 \\
218,0(900)\end{array}$ \\
\hline $\begin{array}{l}\text { Fruiting years: } \\
\text { a) Cultivation } \\
\text { b) Harvesting by harvester } \\
\text { by hand }\end{array}$ & $\begin{array}{l}222 \\
1492(7280)\end{array}$ & $\begin{array}{l}127,0^{1} \\
37,5(3300) \\
210,5(800)\end{array}$ \\
\hline
\end{tabular}

1 averages of methods $\mathrm{A}$ and $\mathrm{B}$

(Table 5). The time spent on establishing the plots and cultivations during fruiting years was about the same in KRẢKEVIK's studies in Norway as in this study. The small size of the plots meant that not all cultivation tasks could be mechanized. As far as the full-grown bushes were concerned, about twice as much time was spent on pruning with shears in KRẢKEVIK's study as in the present one. The main reason for this was probably the varieties cultivated, which needed pruning differently. The man hours consumed in hand picking are not comparable, as hand picking was preceded by mechanical harvester on the study farms in Finland.

According to a Finnish study carried out in 1980 - the HERKO study (LISKOLA et al.) labour output with hand picking was $6,3 \mathrm{~kg} / \mathrm{h}$, whereas in the present study it was $3,8 \mathrm{~kg} / \mathrm{h}$. The lower labour output in the latter case was due to hand picking being produced by mechanical harvesting. The labour output with baton picking was $16,0 \mathrm{~kg} / \mathrm{h}$ in the HERKO-study. In the present study the average labour output was $10,0 \mathrm{~kg} / \mathrm{h}$. This includes cleaning the berries and idle time. A yield of $5000 \mathrm{~kg} / \mathrm{ha}$ was harvested by Joonas harvester in 4,5 hours and 13,5 man hours per hectare were required (LISKOLA et al. 1980). These figures obviously include only the effective working time. In the present study 6,0 machine hours and 37,5 man hours per hectare were consumed when the average yield was $3300 \mathrm{~kg} / \mathrm{ha}$.

The variation in labour consumption is very remarkable and the reasons for this are not easily identified. The cultivation method, cultivation area, size of the yield and the harvesting method account for only appr. $20 \%$ (of) the variation according to regression analysis. In Finland, large scale blackcurrant cultivation is in its very early stages. Less than ten years have elapsed since intensive development started in this field. Growers are just getting to know the different methods, and they have developed their machinery, especially harvesting machines, themselves. Well planned blackcurrant cultivation areas do exist and cultivation and harvesting methods are being rationalized. On the best farms the work done on cultivation was only approx. half the average for both the very slightly mechanized group (A) and the highly mechanized one (B).

Labour consumption in harvesting, will clearly decrease in the future, when cultivations reach normal fruiting level and cultivation methods are developed according to the best known methods. 


\section{References}

KRẢKEVIK, S. 1973. Arbeidsforbruket i solbaerproduksjonen. Forskn. og fors. i landbr. 24, 4: 341-356. LISKOLA, K., TAHVONEN, R. \& HYTÖNEN, T. 1980. Herukan konekorjuu - HERKO. Sitra. Sarja B. 56. 80 p. Helsinki.

YLÄRANTA, M. \& RYYNÄNEN, V. 1981. Consumption of working time in strawberry production. J. Scient. Agric. Soc. Finl. 53: 75-82.

Ms received December 10, 1981 .

\section{SELOSTUS}

\section{Mustaherukan työnmenekki}

\section{Maritta Yläranta ja Viljo Ryynänen}

Maatalousekonomian laitos, Helsingin yliopisto, SF-00710 Helsinki 71

Vuosina 1977-80 tutkittiin mustaherukanviljelyn työnmenekkiä 29 maatilalla. Tutkimuksessa oli mukana yhteensã 136,7 ha mustaherukkaa.

Tyōnmenekki selvitettiin erikseen perustamisvaiheessa, hoitokesānā, ensimmaaisenã satokesănă ja varsinaisina satokesinā. Sadonkorjuuta koskevat havainnot tehtiin koneellisesta korjuusta sekã patukka- ja käsinpoiminnasta.

Perustamisvaiheen ihmistyönmenekki oli koneellista istutusta käytettäessã yhteensã $98,5 \mathrm{~h} / \mathrm{ha}$. Traktoriauralla ajettuihin vakoihin lapiolla istutettaessa ihmistyönmenekki kohosi 147,0 tuntiin hehtaaria kohti. Hoitokesãnã viljelys vaati keskimäärin $83,5 \mathrm{~h} / \mathrm{ha}$ ihmistyötä. Ensimmäisenã satokesänä hoitotöihin kului $87,5 \mathrm{~h} / \mathrm{ha}$. Tutkimusajanjakson marjanviljelylle epäedullisten sääolojen takia ensimmäisen vuoden sato käsinpoimituilla lohkoilla jäi $900 \mathrm{~kg} / \mathrm{ha}$. Käsinpoimintaan käytettiin $218,0 \mathrm{~h} / \mathrm{ha}$. Viljelmillä, joilla käytettiin patukkapoimintaa, sato oli ensimmäisenä kesänā $1800 \mathrm{~kg} / \mathrm{ha}$. Työnmenekki oli $210.0 \mathrm{~h} / \mathrm{ha}$. Täysi-ikäisten kasvustojen hoitotöihin kului käytettäessä vähän koneellistettua menetelmää $158,5 \mathrm{~h} / \mathrm{ha}$ ja käytettäessä koneellistettua menetelmää $95,0 \mathrm{~h} / \mathrm{ha}$. Patukkapoimintaan (sato $4000 \mathrm{~kg} / \mathrm{ha}$ ) käytettiin 400,0 h/ha. Koneelliseen sadonkorjuuseen (sato $3300 \mathrm{~kg} / \mathrm{ha}$ ) tarvittiin konetyồtã $6 \mathrm{~h} / \mathrm{ha} \mathrm{ja} 37,5 \mathrm{~h} / \mathrm{ha}$ ihmistyötaă. Konepoiminnan jällkeen suoritettiin vielä jälkipoiminta käsin (sato $800 \mathrm{~kg} / \mathrm{ha}$ ), johon kāytettiin tyōtä $210,5 \mathrm{~h} / \mathrm{ha}$. Lisäksi tyōnjohtoon ja sekalaisiin töihin kului poimintaaikana $24,5 \mathrm{~h} / \mathrm{ha}$. 